\title{
Battle of the eternal rivals: restoring functional p53 and inhibiting Polo-like kinase 1 as cancer therapy
}

\author{
Frank Louwen ${ }^{1}$ and Juping Yuan ${ }^{1}$ \\ ${ }^{1}$ Department of Gynecology and Obstetrics, School of Medicine, J. W. Goethe-University, Frankfurt, Germany \\ Correspondence to: Juping Yuan, email: yuan@em.uni-frankfurt.de \\ Keywords: Oncotargets \\ Received: June 13,2013 Accepted: July 11,2013 Published: July 13, 2013
}

This is an open-access article distributed under the terms of the Creative Commons Attribution License, which permits unrestricted use, distribution, and reproduction in any medium, provided the original author and source are credited.

\section{ABSTRACT:}

Polo-like kinase 1, a pivotal regulator of mitosis and cytokinesis, is highly expressed in a broad spectrum of tumors and its expression correlates often with poor prognosis, suggesting its potential as a therapeutic target. p53, the guardian of the genome, is the most important tumor suppressor. In this review, we address the intertwined relationship of these two key molecules by fighting each other as eternal rivals in many signaling pathways. p53 represses the promoter of Polo-like kinase 1, whereas Polo-like kinase 1 inhibits p53 and its family members p63 and p73 in cancer cells lacking functional p53. Plk1 inhibitors target all rapidly dividing cells irrespective of tumor cells or non-transformed normal but proliferating cells. Upon treatment with PIk1 inhibitors, p53 in tumor cells is activated and induces strong apoptosis, whereas tumor cells with inactive p53 arrest in mitosis with DNA damage. Thus, inactive p53 is not associated with a susceptible cytotoxicity of Polo-like kinase 1 inhibition and could rather foster the induction of polyploidy/aneuploidy in surviving cells. In addition, compared to the mono-treatment, combination of Polo-like kinase 1 inhibition with anti-mitotic or DNA damaging agents boosts more severe mitotic defects, effectually triggers apoptosis and strongly inhibits proliferation of cancer cells with functional p53. In this regard, restoration of p53 in tumor cells with loss or mutation of p53 will reinforce the cytotoxicity of combined Polo-like kinase 1 therapy and provide a proficient strategy for combating relapse and metastasis of cancer.

\section{INTRODUCTION:}

Polo-like kinase 1 and the tumor suppressor p53

Since the discovery of Polo kinase in Drosophila in 1988 [1], the Polo-like kinase (Plk) family has been attracting enormous attention, both in academia and in pharmaceutical industry. Five members of the Plk family have been discovered in humans and these serine/threonine kinases have emerged as key players by performing crucial functions in the cell cycle, DNA damage response and neuron biology [2-6]. Plk1 is mainly expressed during the late $\mathrm{G} 2$ and $\mathrm{M}$ phase, where it regulates various stages of mitosis [2,7]. Plk2 is an immediate early response gene and is expressed in early G1, where it controls the entry into S phase [8]. Plk3 is expressed throughout the cell cycle and involved in cellular response to DNA damage
[9]. While Plk4 controls centriole duplication [10-12], Plk5 seems to be linked with neuron biology [6].

Plk1, the most thoroughly characterized member among the mammalian Plks, has multiple important roles in mitosis and cytokinesis, such as centrosome maturation, bipolar spindle formation, kinetochore-microtubule dynamics, activation of the anaphase promoting complex, chromosome segregation and execution of cytokinesis $[3,4,13]$. In line with this multitude of proposed functions, Plk1 localizes to centrosomes, mitotic spindles, kinetochores, the central spindle and midbody $[2,14-$ 16]. The Plk1 activity and its Polo-box binding domain (PBD) are required to mediate its localization to mitotic structures [17-21]. It has been recently reported that while dynactin targets Plk1 to kinetochores [22], the cullin 3 (CUL3)-based E3 ubiquitin ligase containing the adaptor KLHL22 ubiquitylates Lys 492 within the PBD and leads to Plk1 dissociation from kinetochore phosphoreceptors 
[23]. In the absence of KLHL22, Plk1 accumulates on kinetochores, resulting in activation of the spindle assembly checkpoint (SAC) [23].

Plk1 strongly promotes progression of the cell cycle and is responsible for aggressive proliferation of tumor cells, regarded as a cellular proliferation marker [24]. Overexpression of Plk1 enables cells to override checkpoints, leading to genomic instability and promoting cell transformation $[7,25,26]$. In support of these interesting data, Plk1 is highly expressed in a broad spectrum of human tumors and its expression often correlates with poor prognosis of tumor patients, suggesting its involvement in oncogenesis and its potential as a therapeutic target $[3,26]$. Interestingly, genome-wide RNAi screening has identified Plk1 as the only kinase selectively required for the viability of activated Ras cancer cells [27]. Moreover, tumor-initiating cells are responsible for tumor maintenance and relapse. Recently, multiple studies have reported that Plk1 is a potential therapeutic target for eliminating tumor-initiating cells in various tumor types [28-32], implying that inhibiting Plk1 could be useful for combating relapse and metastasis of tumors.

Plk1 offers two functional important target domains: a kinase domain at the $\mathrm{N}$-terminus that is closely related to several members of the superfamily of protein kinases, and the unique specific PBD at the $\mathrm{C}$-terminus. Over the years, efforts have been made to identify Plk1 inhibitors, yielding numerous potent compounds that competitively inhibit the catalytic activity and regulatory function of Plk1 [7,33-35]. In concordance with this, several small-molecule inhibitors of Plk1 are currently under clinical trials [7,36-42]. Based on a fluorescence polarization assay, we have identified the natural product thymoquinone (TQ) and its synthetic derivative Poloxin as the first small molecule inhibitors targeting the PBD of Plk1 $[43,44]$. Poloxin exhibits a high specificity toward the PBD of Plk1, interferes with the intracellular localization of Plk1, induces mitotic arrest and chromosome congression defects [43]. It suppresses proliferation and triggers apoptosis in cancer cell lines and inhibits tumor growth in xenograft mouse models as well [44].

The key tumor suppressor p53, discovered in $1979[45,46]$, has become a milestone in cancer biology [47]. p53 has been the focus since the late 1980s, when it became evident that TP53, the gene encoding the p53 protein, was mutated or altered in various human cancers $[48,49]$. As the guardian of the genome [50], p53 plays crucial roles in DNA repair, cell cycle arrest, apoptosis, senescence, differentiation, cell adhesion, cell mobility, aging, autophagy, cellular metabolism and somatic cell reprogramming of stem-cell biology [51-59]. p53 functions as a tetramer and its $\mathrm{N}$-terminal region consists of an intrinsically disordered transactivation domain and a proline-rich region, followed by the central, folded DNA-binding core domain for sequence-specific DNA binding, a flexible linker, a short tetramerization domain regulating the oligomerization, and finally the regulatory domain at its C-terminus binding DNA nonspecifically [60]. At homeostasis, the steady-state level of p53 is kept low and $\mathrm{p} 53$ function is repressed mainly by the negative regulators mouse double minute 2 (MDM2, human ortholog HDM2) and MDMX (human ortholog HDMX) [61]. p53 is activated in response to oncogenic activation,

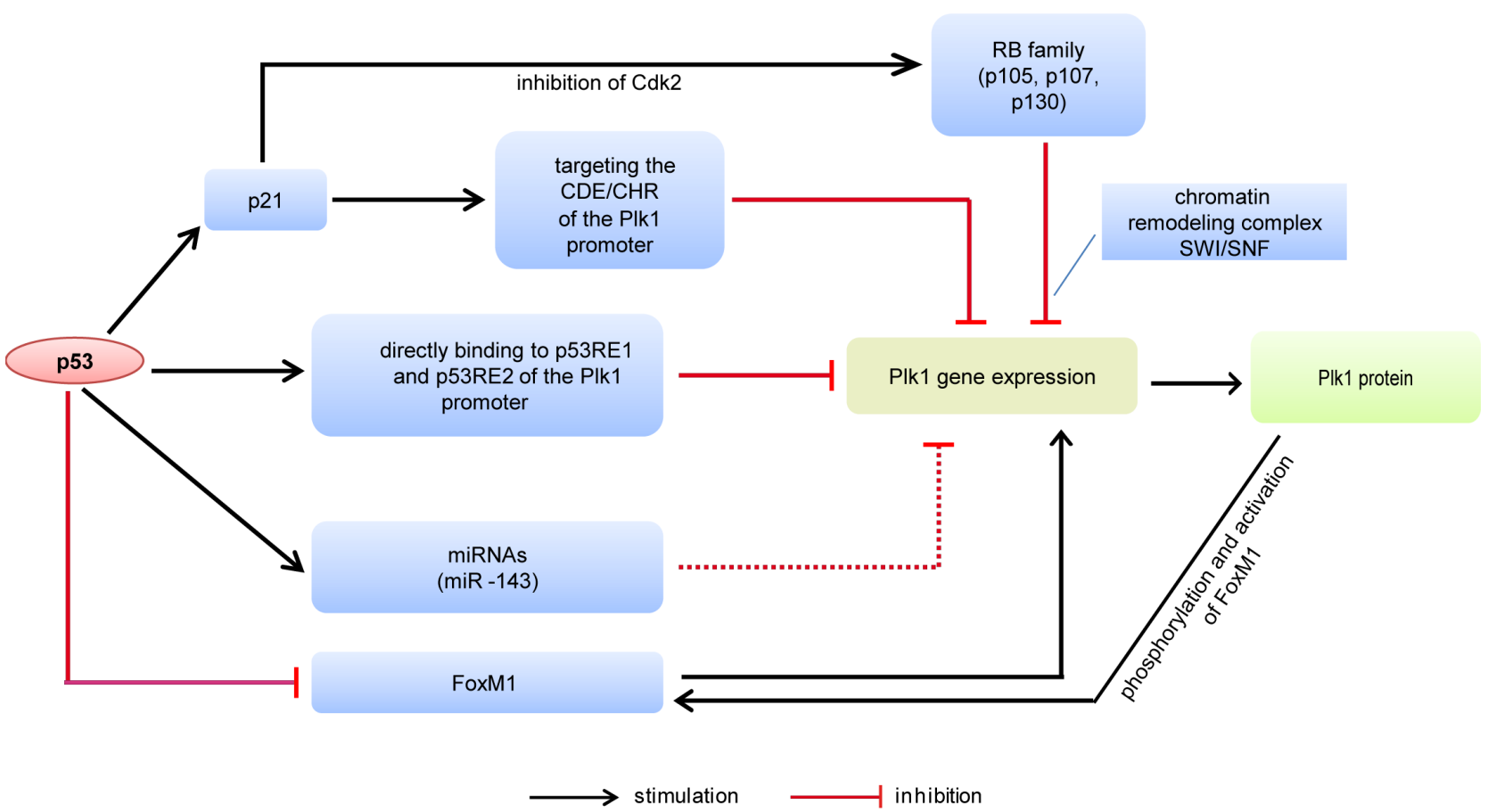

Figure 1:Schematic representation of the Plk1 gene expression controlled by p53. CDE/CHR, cell cycle-dependent element and cell cycle genes homology region. RB, retinoblastoma. FoxM1, forkhead box M1. p53RE, p53 response element. miRNA, micro-RNA. 
DNA damage, telomere erosion, ribosomal stress, loss of cell-cell or cell-matrix adhesion, hypoxia or other cellular stress [62]. Its activity and cellular level are tightly controlled by a multitude of regulatory proteins, involving diverse posttranslational modifications $[63,64]$. Loss of p53 function occurs in most human tumors by either mutation of TP53 itself or by inactivation of the p53 signal transduction pathway $[52,65,66]$. Therefore, awakening the guardian of the genome by drugging the p53 pathway could have wide applications in fighting cancer $[66,67]$.

During our studies on Plk1 we have very often observed that Plk1 crosses the signaling pathways of p53 and vice versa. In the present review we have focused on the intertwined relationship between the key tumor suppressor p53 and the key mitotic kinase Plk1. We have summarized the function of p53 in mitosis under cellular stress. Finally, we have dealt with the impact of p53 on efficacy of Plk1 inhibitors in tumor cells.

\section{p53 represses the Plk1 promoter, directly and indirectly}

In an early report based on the deletion analysis of the Plk1 promoter, several regions have been identified to contribute to the transcriptional regulation of Plk1 [68]. The potential binding sites for transcription factors E2A, AP1, AP2, SP1, NF-Y and NFאB could be identified in a computer-based search [68]. A stretch of 300 base pairs immediately $5^{\prime}$ of the transcription start site of the Plk1 promoter contains a CCAAT motif essential for promoter activity [68]. The mRNA expression of Plk1 is low at the
G1/S boundary, increases in the S phase, and is maximally expressed during the $\mathrm{G} 2 / \mathrm{M}$ transition. Based on promoter luciferase assays, three activating regions have been identified between 35 and 93 base pairs upstream of the transcription initiation site [69]. A repressor element, termed the cell cycle-dependent element and the cell cycle genes homology region (CDE/CHR), is located in the region of the transcription start site in the Plk1 promoter and mutations within this element diminished cell cycle regulation of transcription [69].

The Plk1 gene is mainly suppressed by p53 and the retinoblastoma (RB) pathway (Fig. 1). p21/waf1 (p21), the downstream effector of $\mathrm{p} 53$, inhibits the Plk1 expression partly by targeting sequences CDE and CHR in the Plk1 promoter [70]. p53 negatively regulates the expression of the forkhead box M1 (FoxM1) [71,72], an oncogenic transcription factor, which stimulates Plk1 expression [73]. On the other hand, the transcriptional activation of FoxM1 is dependent upon the phosphorylation by Plk1 [74]. In addition, the RB family members, p130, p107 and p105, play key roles in transcriptional repression of the Plk1 gene $[75,76]$. The RB pathway activation results in repression of the Plk1 promoter activity, which is dependent on the chromatin remodeling complex SWI/ SNF [75].

Not only indirectly but also directly, p53 regulates the Plk1 expression. Recently, it has been reported that p53 is both necessary and sufficient to mediate a transcriptional repression of the Plk1 promoter [77]. Repression of the Plk1 gene by p53 occurs independently of p21 and of $\mathrm{CDE} / \mathrm{CHR}$ element upon DNA damage. It is further

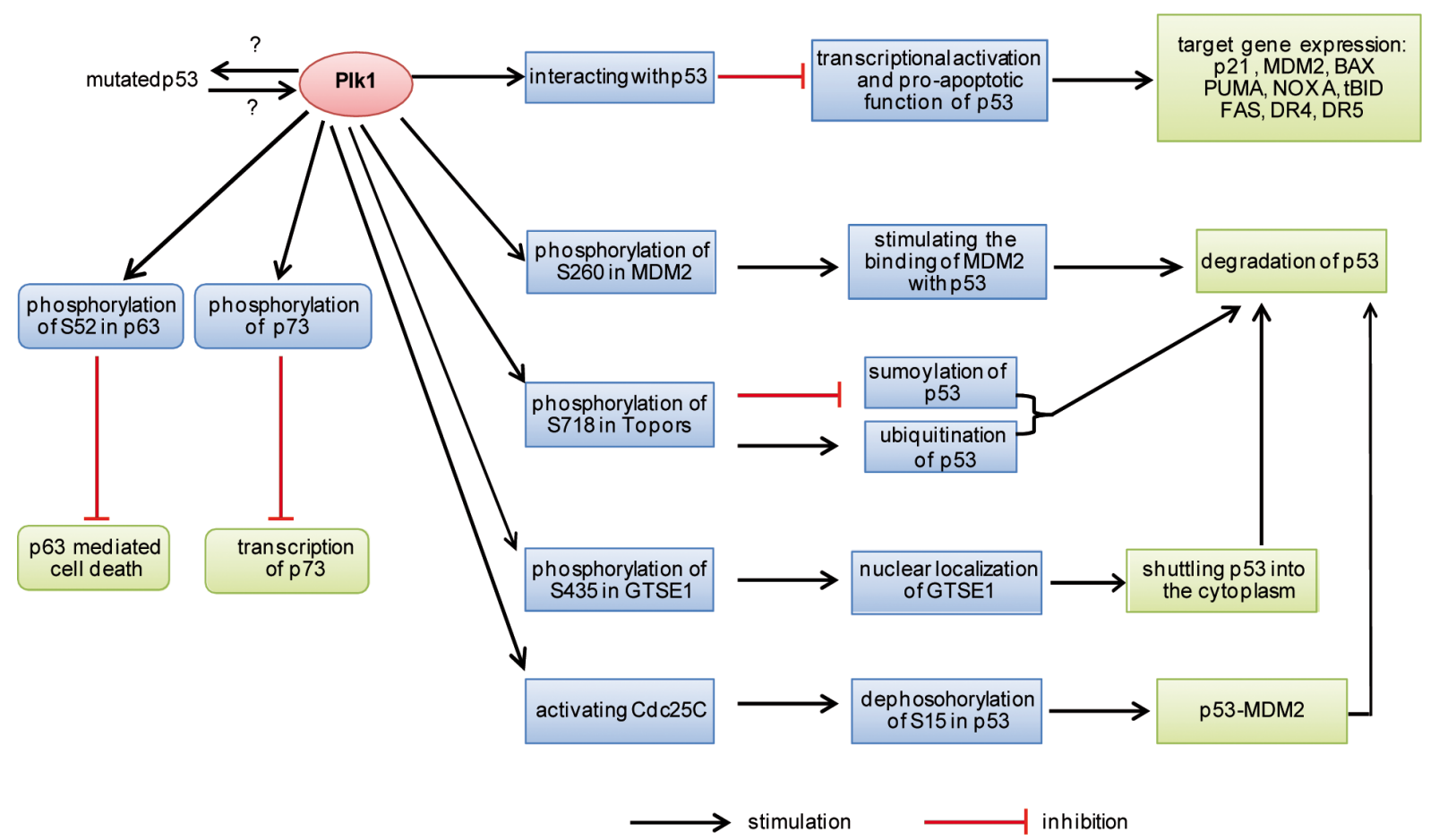

Figure 2:Summary of p53 inactivation by Plk1. MDM2, mouse double minute 2; Topors, topoisomerase I-binding protein. GTSE1, a G2 and S-phase-expressed 1 protein. 
demonstrated that $\mathrm{p} 53$ binds to the Plk1 promoter at two distinct sites termed p53 response element 1 (p53RE1) and p53RE2 based on chromatin immunoprecipitation analysis [77]. Recruitment of p53 to p53RE2, but not to p53RE1, is stimulated in response to DNA damage and/ or p53 activation. In addition, wild type p53 represses the promoter expression of Plk1 when fused upstream of a reporter gene [77]. These data strongly suggest that p53 is a major regulator for a proper expression of the Plk1 gene in normal cell cycle progression and upon cellular stresses by controlling the promoter of Plk1, directly or indirectly.

Besides direct transcriptional regulation in the promoter, p53 controls also the target gene expression post-transcriptionally via inducing micro-RNAs (miRNAs), such as miR-34 family [78] and miR-200 family [79]. Recent studies have shown that miR-143, miR-100, miR-593* and miR-10b* target the Plk1 expression in cancer cells [80-85]. It will be of importance to further decipher whether $\mathrm{p} 53$ is behind those miRNAs affecting Plk1 expression.

In accordance with the findings from molecular research, it has been reported that immunohistochemical staining of Plk1 in primary breast tumors was significantly associated with the presence of non-functional mutated $\mathrm{p} 53$, which predicted a significantly worse survival than those with either Plk1 expression or TP53 mutation alone [86]. More studies are needed to explore if overexpression of Plk1 correlates with loss of p53, non-functional p53 or gain-of-function (GOF) mutant p53 in tumor tissues, and if this correlation is linked to therapy resistance and poor prognosis of tumor patients. In particular, the relationship between the Plk1 expression and GOF mutant p53 should be delineated, since GOF p53 mutants, supported very often by other molecules like Pin1 [87], have widespread genomic locations and profoundly affect gene expression by being tethered by other transcriptional factors to their locations and by binding with p63 to its consensus elements $[88,89]$.

\section{Plk1 inhibits the function of p53, directly and indirectly}

On the other hand, Plk1 is not willing to be obedient with the supervision of $\mathrm{p} 53$. Mounting evidence suggests that Plk1 negatively regulates p53 through direct and indirect mechanisms. Plk1 physically binds to the tumor suppressor p53 and inhibits its transactivation activity as well as its pro-apoptotic function in H1299 cells [90]. Immunoprecipitation analyses using a series of deletion mutants of p53 reveal that a sequence-specific DNAbinding region of p53 is required and sufficient for the physical interaction with Plk1. Expression of exogenous Plk1 and p53 in lung carcinoma H1299 cells deficient in p53 greatly decreased the p53-mediated transcription of the p53-responsive $\mathrm{p} 21$, MDM2, and BAX promoters, whereas the kinase-deficient mutant Plk1 failed to reduce the transcriptional activity of p53 [90], suggesting that Plk1-mediated negative regulation of p53 might be a fundamental mechanism for the role of Plk1 in oncogenesis. As various point mutations occur most often in the DNA-binding region of p53 in primary cancers, it will be important to define whether and which point mutation in the DNA binding domain of p53 interferes with the interaction of Plk1. It is tempting to assume that mutated p53 is capable of escaping the inhibition of Plk1via interrupted interaction.

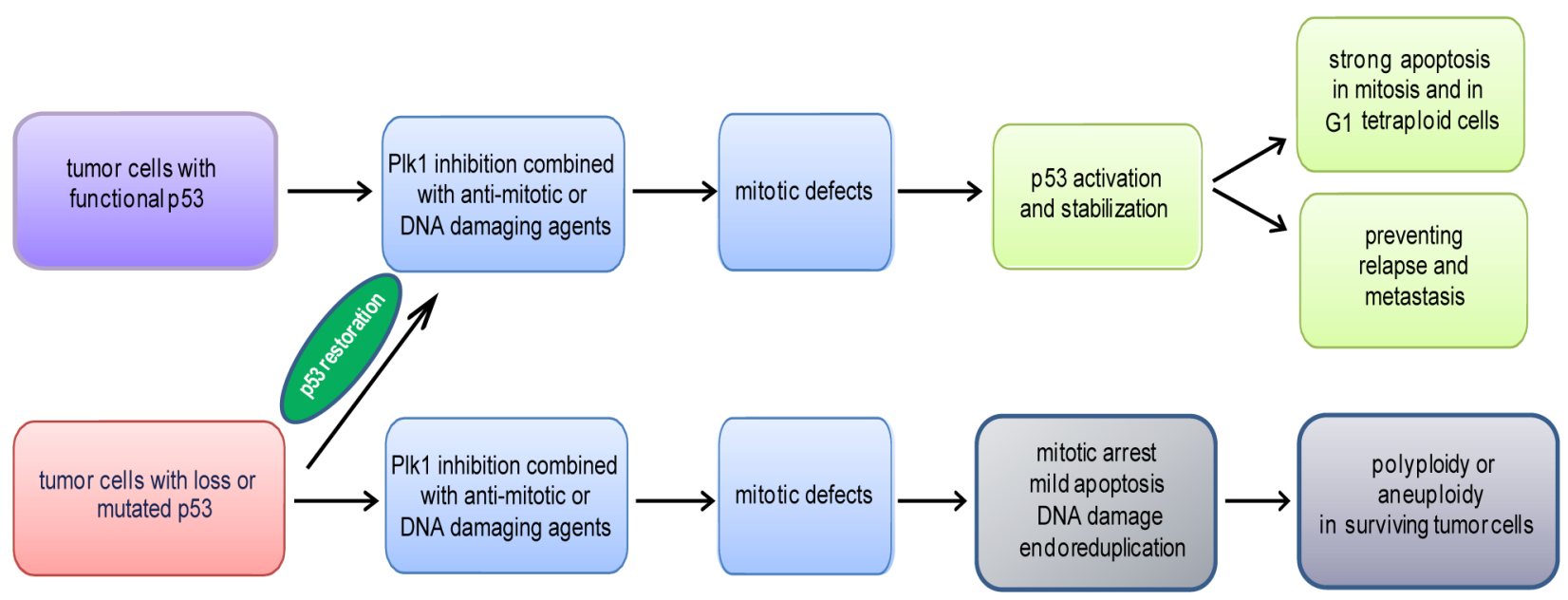

Figure 3:Schematic illustration of the impact of the p53 status on the efficacy of Plk1 inhibition. Mono-therapy of Plk1 inhibition shows a moderate effect in clinical trials, suggestive of combined therapy with other agents, such as anti-mitotic or DNA damaging drugs. Tumor cells with functional p53 respond to Plk1 combined therapy with severe mitotic defects, activation of p53 followed by strong apoptosis in mitosis and in G1 tetraploidy. As p53 is involved in the regulation of the self-reprogramming of cancer stem cells and Plk1 inhibitors target the tumor initiating cells, it is conceivable to suggest that this strategy could empower cancer therapy by preventing relapse and metastasis. p53 restoration in tumor cells with loss or mutated p53 will reinforce the efficacy of Plk1 combined therapy. Otherwise, upon Plk1 combined therapy, tumor cells without functional p53 exhibit a modest apoptosis, DNA damage in mitosis, a longer mitosis linked to endoreduplication, which could make surviving tumor cells more malignant. 
p53 inactivation by Plk1 is further underscored by other studies [91-94]. MDM2 is a pivotal E3 ubiquitin ligase and suppresses p53 by proteasomal degradation and transcriptional inactivation [61]. Plk1 phosphorylates S260 in MDM2 and stimulates MDM2-mediated turnover of p53 [93]. Moreover, phosphorylation of S15 in p53 is required for blocking its interaction with MDM2 and contributes to its stabilization [61]. Overexpression of Plk1 decreases phosphorylation of p53 at S15 in UV induced mitotic HEK293 cells via Cdc25C, a phosphatase activated by Plk1 dependent phosphorylation [91]. Thus, this scenario results in inactivation of p53 by Plk1. Furthermore, Plk1 phosphorylates S718 of the topoisomerase I-binding protein (Topors) [92]. Topors has both ubiquitin and SUMO-1 E3 ligase activity and binds also to p53. Expression of a Plk1-unphosphorylatable Topors mutant (S718A) leads to a dramatic accumulation of p53 through blocking its degradation. Plk1-mediated phosphorylation of Topors suppresses the sumoylation of p53, whereas p53 ubiquitination is enhanced, leading to its degradation [92]. In addition, GTSE1, a G2 and S-phase-expressed 1 protein and a negative regulator of p53, is required for the G2 checkpoint recovery. Plk1 phosphorylation of GTSE1 at S435 promotes its nuclear localization and thus shuttles p53 out of the nucleus for its degradation during the recovery [94]. These results are consistent with a previous report that p53 is stabilized in Plk1-depleted HeLa cells [95]. Thus, these data strongly suggest that Plk1 inhibits its rival p53 through either directly physical binding to block its function or indirectly inactivating p53 by promoting its turnover, as illustrated in Fig. 2.

\section{Plk1 inhibits p73 and p63 in cancer cells lacking functional p53}

The battles take place not only between Plk1 and the founding member p53 but also between Plk1 and p73/ p63, other two transcription factors of the p53 family. p73 and p63 are expressed as two predominant isoform classes resulting from alternative promoter usage: the TAp73/ TAp63 isoforms contain an N-terminal transactivation domain and most resemble $\mathrm{p} 53$, while the $\Delta \mathrm{Np} 73 /$ $\Delta \mathrm{Np} 63$ isoforms exhibit a truncated $\mathrm{N}$-terminus [96,97]. It is recently reported that the p73/p63 homeostasis is controlled by a microRNA-dependent circuit [96].

p73 has been implicated in cell cycle regulation, apoptosis and developmental processes [98]. In cisplatin mediated apoptosis in COS7 cells, in which the endogenous p53 is inactivated by SV40 large T antigen, p73 is accumulated in association with a significant down-regulation of Plk1 [99]. Reciprocally, Plk1 reduces the stability of the endogenous p73 and depletion of Plk1 stabilizes p73. p73 is phosphorylated at T27 by Plk1 in kinase assay in vitro [99]. Further analyses demonstrate that p73 binds to the kinase domain of Plk1 through its
N-terminal region and wild type Plk1 is able to block the p73-mediated transcriptional activation [99]. Interestingly, Plk1 K82M, a kinase-deficient mutant, binds still to p73 but fails to inactivate the p73-mediated transcriptional activation, suggesting that the catalytic activity of Plk1 is not necessary for the binding but required for the functional inhibition of p73 [99]. Plk1 inhibits p73mediated transcriptional activity is further supported by another study [100]. In addition, Plk1 knockdown enhances cisplatin chemosensitivity via upregulation of p73 in p53 mutant human epidermoid squamous carcinoma cells [101]. We have also observed that the long-term suppression of Plk1 increases the level of the cyclin dependent kinase inhibitor $\mathrm{p} 21$, which is partially induced by elevated tumor suppressor p73 in HeLa cells [102], in which p53 is inactivated via the E6 protein encoded by the oncogenic human papillomavirus (HPV) [103]. Collectively, these findings indicate that Plk1 inhibits $\mathrm{p} 73$ by blocking its function and increasing its degradation in cancer cells lacking functional p53.

p63, the remaining member of the p53 family, is unable to get away from the ruling of Plk1. Immunoprecipitation and in vitro pull-down assay reveal that p63 binds to the kinase domain of Plk1 through its DNA-binding region [104]. Plk1 phosphorylates p63 at S52 of the transactivating domain, which is associated with decreased stability of $\mathrm{p} 63$ protein and suppressed p63 mediated cell death [104]. Furthermore, Plk1 knockdown in p53-mutated liver tumor cells transactivates PUMA, p21 and 14-3-3sigma, and induces apoptosis [104]. Therefore, Plk1 also controls p63 by phosphorylation and regulates apoptotic cell death in liver tumor cells, in which p53 is inactive.

\section{Plk1 inhibitors impact both tumor and normal but proliferating cells}

Plk1 has been widely established as one of the most promising targets for molecular intervention. Multiple small molecule inhibitors targeting the ATP-binding pocket of the kinase domain and its inactive conformation have been developed [7,33-35]. Among them, BI 2536 and BI 6727 are the most intensively investigated Plk1 inhibitors [105-107]. The results from cancer cell lines and from mouse xenograft models suggest their potent anti-cancer activity $[105,107]$. In parallel to the kinase domain, the PBD, the regulatory domain of Plk1, has been suggested as a more ideal target due to its unique nature which facilitates the development of specific agents [17]. Indeed, small molecules or peptides targeting the PBD domain of Plk1 have been developed and investigated $[43,44,108,109]$. The data from Plk1 inhibitors, targeting either the kinase domain or the PBD, are inspiring, based on cell culture systems or xenograft mouse models. However, the clinical results are rather less encouraging by showing limited anti-cancer activity [38,40,110,111]. 
To identify the molecules and signaling pathways, which are responsible for the cytotoxicity of Plk1 inhibitors, is fundamental for selecting suitable tumor patients for treatment.

It has been widely proposed that Plk1 depletion/ inhibition preferentially kills cancer cells compared with normal cells [112-115]. This leads to the hypothesis that Plk1 inhibition is specific and selective by targeting only cancer cells but not normal cells. However, during characterization of the PBD inhibitor Poloxin, we clearly observed that Poloxin inhibited proliferation of a panel of tumor cells as well as several primary/normal nontransformed but proliferating cells, with a comparable efficiency [44]. Proliferation of exponentially normal growing cells, including retinal primary epithelial cells hTERT-RPE1, human umbilical vein endothelial cells (HUVEC), mammary epithelial MTSV-1 cells and fibroblasts, was suppressed upon Poloxin treatment with comparable EC50 values, suggestive of a similar sensitivity of normal cycling cells to Plk1 inhibition. Our observation is supported by the data from other studies of Plk1 inhibitors, such as BI 2536 and the PBD inhibitor purpurogallin (PPG), impacting both cancer cells as well as normal cells with a comparable sensitivity $[107,109,116]$. Recently, it has been shown that depletion of Plk1 suppresses the viability of MCF10A, a nontransformed mammary epithelial cell line, even more strongly than that of cancer cell line MDA-MB-468 in monolayer cell culture system [117]. Under 3D culture condition, however, MCF10A cells recapitulate epithelial morphogenesis by forming acinar structures and then stop to grow, whereas cancer MDA-MB-468 cells exhibit disorganized structures and continue to proliferate. BI 2536, added to these structures once formed, was effective on MDA-MB-468, and had no effect on MCF10A cells [117]. This is ascribed to the fact that MCF10A cells do not proliferate once the acinar structure is formed. Thus, the sensitivity to Plk1 inhibitors possibly depends on the doubling time of individual cell lines in a monolayer cell culture system and in 3D culture model as well. Given the essential role of Plk1 during mitosis, it is conceivable to propose that Plk1 inhibitors target all rapidly dividing cells irrespective of tumor or normal cells, which is consistent with observed adverse effects of Plk1 inhibitors in clinical trials [38,111,118].

\section{p53 is pivotal for faithful mitotic progression}

Furthermore, it has been reported that Plk1 depletion/inhibition preferentially kills p53 defective cancer cells compared with p53 wild type cancer cells $[119,120]$. This association of non-functional p53 with sensitivity of Plk1 inhibition leads to the second assumption that inactive p53 facilitates the cytotoxicity of Plk1 inhibition and tumor patients with p53 deficiency/ mutation may preferentially benefit from treatment with
Plk1 inhibitors.

p53 is localized at centrosomes, mitotic spindles, the centromeres, the midzone/cleavage furrow in mitosis [121-123] and is activated in response to various mitotic stresses such as aberrant spindle formation, abnormal centrosome separation and chromosome damage or missegregation [124-126], suggestive of p53 role in mitosis. p53 knockdown leads to high percentages of cells with abnormal amplification of centrosomes $[10,127]$ and p53 is an important negative regulator of the mitotic kinase Aurora A [128]. p53 localization at the centrosomes in mitosis is ataxia-telangiectasia mutated (ATM)-dependent and monitors mitotic spindle integrity in mitosis $[122,129,130]$, leading to the proposal that ATM and p53 might contribute to the "centrosomal checkpoint", a network that integrates cell cycle arrest and repair signals [131,132]. p53 is involved in facilitating chromosome segregation to ensure the maintenance of diploid cells [133] and is required for cell cycle arrest after erroneous tetraploid mitosis [134]. Phosphorylation of serine 10 in histone H3 by Aurora B kinase is critical for maintaining normal ploidy, which is coupled with histone deacetylases I/II activity at lysine K9 [135]. Acetylation of K9 and phosphorylation of S10 are interestingly associated in a p53-dependent manner [136]. In addition, p53 is required to enable cells to recover from a nocodazole-induced prometaphase arrest and to coordinate mitotic events $[135,136]$. The data indicate that p53 is involved in remodeling and reorganizing chromatin structure in mitosis upon stress. Moreover, the spindle assembly checkpoint (SAC) is essential for proper sister chromatid segregation in mitosis. BubR1, an important kinase of the SAC, interacts with and phosphorylates p53 in mitotic cells and regulates protein stability of p53 in mitosis [137]. Mps1, another spindle checkpoint kinase, phosphorylates p53 at T18, which stabilizes and activates p53 in mitosis [138]. This phosphorylation disrupts the interaction with MDM2 and abrogates MDM2-mediated p53 ubiquitination [138]. Mps1 and BubR1 mediated p53 phosphorylation are required for $\mathrm{p} 53$ activation to properly induce cell death in a p53-dependent manner in response to mitotic spindle damage $[137,138]$. Inhibition of Mps 1 or BubR1 appears to be disabling a p53-mediated cell death signaling pathway, contributing to accumulation of polyploidy/aneuploidy cells in response to mitotic spindle damage or oncogene-induced DNA damage [137,139]. These data indicate that activation of p53 is essential for protecting cells from genome instability caused by various mitotic failures.

\section{Inactive p53 is not a predictor for the efficacy of Plk1 inhibitors}

We were wondering if the p53 status is indeed a key determinant for the cytotoxic response to Plk1 
inhibition in cancer cells. To address this issue, we have examined the cytotoxicity of Plk1 inhibitors/depletion in various cancer cell lines with or without functional p53 [126]. We observed that cancer cells without p53 displayed no increased cytotoxicity upon treatment with different Plk1 inhibitors or siRNA against Plk1. In fact, cancer cells with wild type p53 showed more apoptosis upon Plk1 inhibition, compared to cancer cells without p53 [126]. Our observation is in line with the study by Sur and colleagues that cancer cell lines with or without p53 displayed only minor difference in the sensitivity of the Plk1 inhibitor BI 2536 [140], arguing against a direct role of defective p53 in the response to Plk1 inhibition. Moreover, we examined whether mitotic stress impacted the efficacy of Plk1 inhibitors in cancer cells with or without $\mathrm{p} 53$. In the presence of mitotic stress induced by different agents, HCT116 p53+/+ cells displayed a strong apoptosis after treatment with Plk1 inhibitors with increased pro-apoptotic protein Bax, whereas HCT116 p53-/- cells arrested in mitosis with activation of the spindle checkpoint and DNA damage, followed by a mild apoptosis with enhanced anti-apoptotic proteins Bcl-2 and Mcl-1 [141]. Moreover, the surviving HCT116 p53/- cells showed a strong capability of colony formation. Thus, under severe mitotic stress induced by combined therapy, HCT116 p53+/+ cells conduct apoptosis in mitosis or exit mitosis into the G1 tetraploidy followed by p53-dependent apoptosis, whereas HCT116 p53-/cells arrest in mitosis, possibly to initiate another round of DNA replication as suggested [142,143]. In this regard, Plk1 inhibition in cancer cells with inactive p53 could lead to an accumulation of polyploidy/aneuploidy, due to the lack of p53-mediated cell death signaling pathway. Taken together, we suggest that loss of p53 is not directly associated with the sensitive cytotoxicity of Plk1 inhibition. Further investigations are required to study whether the long-term outcomes of losing p53, such as compromised or defective DNA damage checkpoint, abnormal metabolism and low differential grade, which possibly make the survival of tumor cells more dependent on Plk1 function, are responsible for the cytotoxicity of Plk1 inhibition.

\section{Combination of inhibiting Plk1 and restoring p53 as cancer therapy}

Whereas inhibiting the initial phases of the cell cycle is likely to generate viable quiescent cells, targeting mitosis offers possibility for killing cancer cells [144]. Mitosis is the most vulnerable phase of the cell cycle, during which it is susceptible to induce cell death with various insults. Microtubule poisons have been proven to be efficacy in clinic against a broad range of malignancies, yet they affect both dividing and non-dividing cells inducing unwished side-effects [145]. It is therefore much desired to develop a new generation of anti-mitotic drugs which target key proteins with specific functions in mitosis, such as Plk1 $[7,144]$ or mitotic centromereassociated kinesin [146]. Several clinical trials of the Plk1 inhibitor BI 2536 have been performed in different tumor types [38,39,110,118] and the mono-therapy of Plk1 inhibitors has shown modest efficacy [38,39,111], suggestive of combined strategy. Interestingly, retinoids enhance the effectiveness of Plk1 inhibitor GSK461364 [147]. In xenograft mouse models, administration of BI 2536 combined with doxorubicin and cyclophosphamide leads to a faster complete response compared with chemotherapy alone and prevents relapse in the poor prognosis-associated triple-negative breast cancer [117]. Plk1 inhibition suppresses proliferation and enhances radiation sensitivity in medulloblastoma cell lines [30]. These data are in consistence with our data that the combination of Plk1 inhibition with anti-mitotic or DNA damaging agents triggers more apoptosis and inhibits more strongly proliferation of cancer cells compared to the mono-treatment [102,141,148,149]. In particular, both Plk1 inhibitors and microtubule-inhibitory agents prolong mitotic arrest, promoting p53 stabilization, Bax expression, caspase activation and apoptosis induction [126,150-152]. In fact, the first clinical trial of Plk1 inhibitor BI 2536 combined with DNA damage agent pemetrexed demonstrates an encouraging antitumor activity in relapsed non-small-cell lung cancer [153]. The combination will synergistically generate cytotoxicity and reduce unwished side-effects of both Plk1 inhibitor and anti-mitotic or DNA damage agent by reducing the dosage of each drug.

The frequent inactivation of p53 in tumors fosters the attractive notion that its functional restoration would constitute an effective tumor-specific therapy. Strategies aimed at restoring wild type p53 function in tumors with p53 loss, mutation or inhibition have been actively pursued and some have already reached clinical trials [67]. The therapeutic impact of those strategies in human cancer has been recently modeled in mice where a clear, even if limited, therapeutic benefit of p53-targeted therapies is established. Thus, restoration of p53 is a powerful strategy for molecular cancer therapy. In tumor cells with wild type p53 or wild type but inactive p53, such as HeLa cells, Plk1 inhibition induces mitotic cellular stress and activates p53 leading further to a strong induction of apoptosis [126]. In tumor cells with loss or mutation of p53, restoration of p53 will empower the cytotoxicity of Plk1 inhibitors by strongly inducing apoptosis. Furthermore, it is conceivable to suggest that restoration of p53 and inhibition of Plk1 will synergistically hinder relapse and metastasis of cancer, as p53 controls stem cell reprogramming and Plk1 inhibition eliminates tumor-initiating cells [2831]. Finally, it has been reported that BI 2536 generates aneuploidy in primary cardiac fibroblasts [116]. Thus, reactivation of functional p53 will be able to prevent the 
genome instability caused by Plk1 inhibitors in surviving tumor or normal but proliferating cells. Collectively, reinstallation of functional p53 in tumor cells with loss or mutation p53 will brighten the way for a high efficiency of Plk1 inhibition, combined with anti-mitotic or DNA damage agents. This strategy will fight cancer with a more powerful efficacy by targeting not only proliferation but also relapse and metastasis of tumor cells. Since normal cells have wild type p53, more investigations are needed to identify predictive biomarkers for each combination to maximize efficacy and minimize side-effects in the context of administration schedules, such as succession and dosage, in individual tumors based on the molecular working mechanisms. Hopefully, we will reach the goal of cancer therapy that "the wolves are sated, and the sheep are intact" $[154,155]$.

\section{SUMMARY}

Plk1 and p53 intertwine and suppress each other in many signaling pathways. In the context of the association between the p53 status and Plk1 inhibition, we have addressed two issues: first, targeting Plk1 impacts actually all rapidly dividing cells irrespective of tumor cells or normal cells, which is in line with the crucial role of Plk1 in mitosis; second, tumor cells with functional p53 exhibit a stronger apoptosis than tumor cells with inactive p53. In addition, compared to the mono-therapy, combination of Plk1 inhibition with anti-mitotic or DNA damage agents induces more severe mitotic defects followed by apoptosis, and inhibits more strongly proliferation of cancer cells with functional p53. In this regard, restoration of p53 in tumor cells with loss or mutation of p53 will promote the cytotoxicity of combined Plk1 therapy, prevent genome instability induced by Plk1 inhibitors, and provide an effective strategy for combating relapse and metastasis of cancer (Fig. 3). A better understanding is required to maximize efficacy and minimize side-effects of combined Plk1 therapy in terms of administration schedules, such as succession and dosage, in each individual tumor.

\section{ACKNOWLEDGEMENTS}

The work at our laboratory is supported by Deutsche Krebshilfe \#108553 and \#109672, by Deutsche Forschungsgemeinschaft \#Yu 156/2-1, and by Oncogene Signal-transduction Frankfurt (OSF). We apologize to colleagues whose contributions are not cited due to space limitation. We thank Ms. Friemel for her skillful art work of illustrations. We also thank our colleagues for helpful discussion and critical reading.

\section{Conflict of Interest}

The authors declare no conflict of interest.

\section{REFERENCES}

1. Sunkel CE, Glover DM: polo, a mitotic mutant of Drosophila displaying abnormal spindle poles. J Cell Sci 1988, 89 ( Pt 1): 25-38.

2. Barr FA, Sillje HH, Nigg EA: Polo-like kinases and the orchestration of cell division. Nat Rev Mol Cell Biol 2004, 5: 429-440.

3. Strebhardt K, Ullrich A: Targeting polo-like kinase 1 for cancer therapy. Nat Rev Cancer 2006, 6: 321-330.

4. Archambault V, Glover DM: Polo-like kinases: conservation and divergence in their functions and regulation. Nat Rev Mol Cell Biol 2009, 10: 265-275.

5. Bruinsma W, Raaijmakers JA, Medema RH: Switching Polo-like kinase-1 on and off in time and space. Trends Biochem Sci 2012, 37: 534-542.

6. de CG, Manning G, Malumbres M: From Plk1 to Plk5: functional evolution of polo-like kinases. Cell Cycle 2011, 10: $2255-2262$.

7. Strebhardt K: Multifaceted polo-like kinases: drug targets and antitargets for cancer therapy. Nat Rev Drug Discov 2010, 9: 643-660.

8. Ma S, Charron J, Erikson RL: Role of Plk2 (Snk) in mouse development and cell proliferation. Mol Cell Biol 2003, 23: 6936-6943.

9. Bahassi eM, Conn CW, Myer DL, Hennigan RF, McGowan $\mathrm{CH}$, Sanchez Y, Stambrook PJ: Mammalian Polo-like kinase $3(\mathrm{Plk} 3)$ is a multifunctional protein involved in stress response pathways. Oncogene 2002, 21: 6633-6640.

10. Holland AJ, Fachinetti D, Zhu Q, Bauer M, Verma IM, Nigg EA, Cleveland DW: The autoregulated instability of Polo-like kinase 4 limits centrosome duplication to once per cell cycle. Genes Dev 2012, 26: 2684-2689.

11. Holland AJ, Fachinetti D, Da CS, Zhu Q, Vitre B, LinceFaria M, Chen D, Parish N, Verma IM, Bettencourt-Dias M, Cleveland DW: Polo-like kinase 4 controls centriole duplication but does not directly regulate cytokinesis. Mol Biol Cell 2012, 23: 1838-1845.

12. Nigg EA: Centrosome duplication: of rules and licenses. Trends Cell Biol 2007, 17: 215-221.

13. Petronczki M, Lenart P, Peters JM: Polo on the Rise-from Mitotic Entry to Cytokinesis with Plk1. Dev Cell 2008, 14: 646-659.

14. Golsteyn RM, Schultz SJ, Bartek J, Ziemiecki A, Ried T, Nigg EA: Cell cycle analysis and chromosomal localization of human Plk1, a putative homologue of the mitotic kinases Drosophila polo and Saccharomyces cerevisiae Cdc5. J Cell Sci 1994, 107 ( Pt 6): 1509-1517.

15. Lee KS, Yuan YL, Kuriyama R, Erikson RL: Plk is an M-phase-specific protein kinase and interacts with a kinesin-like protein, CHO1/MKLP-1. Mol Cell Biol 1995, 15: 7143-7151.

16. Arnaud L, Pines J, Nigg EA: GFP tagging reveals human Polo-like kinase 1 at the kinetochore/centromere region of 
mitotic chromosomes. Chromosoma 1998, 107: 424-429.

17. Elia AE, Rellos P, Haire LF, Chao JW, Ivins FJ, Hoepker K, Mohammad D, Cantley LC, Smerdon SJ, Yaffe MB: The molecular basis for phosphodependent substrate targeting and regulation of Plks by the Polo-box domain. Cell 2003, 115: 83-95.

18. Lee KS, Park JE, Kang YH, Zimmerman W, Soung NK, Seong YS, Kwak SJ, Erikson RL: Mechanisms of mammalian polo-like kinase 1 (Plk1) localization: selfversus non-self-priming. Cell Cycle 2008, 7: 141-145.

19. Hanisch A, Wehner A, Nigg EA, Sillje HH: Different Plk1 functions show distinct dependencies on Polo-Box domainmediated targeting. Mol Biol Cell 2006, 17: 448-459.

20. Qi W, Tang Z, Yu H: Phosphorylation- and polo-boxdependent binding of Plk1 to Bub1 is required for the kinetochore localization of Plk1. Mol Biol Cell 2006, 17: 3705-3716.

21. Kang YH, Park JE, Yu LR, Soung NK, Yun SM, Bang JK, Seong YS, Yu H, Garfield S, Veenstra TD, Lee KS: Self-regulated Plk1 recruitment to kinetochores by the Plk1-PBIP1 interaction is critical for proper chromosome segregation. Mol Cell 2006, 24: 409-422.

22. Yeh TY, Kowalska AK, Scipioni BR, Cheong FK, Zheng M, Derewenda U, Derewenda ZS, Schroer TA: Dynactin helps target Polo-like kinase 1 to kinetochores via its lefthanded beta-helical p27 subunit. EMBO J 2013.

23. Beck J, Maerki S, Posch M, Metzger T, Persaud A, Scheel H, Hofmann K, Rotin D, Pedrioli P, Swedlow JR, Peter M, Sumara I: Ubiquitylation-dependent localization of PLK1 in mitosis. Nat Cell Biol 2013.

24. Yuan J, Horlin A, Hock B, Stutte HJ, Rubsamen-Waigmann $\mathrm{H}$, Strebhardt K: Polo-like kinase, a novel marker for cellular proliferation. Am J Pathol 1997, 150: 1165-1172.

25. Smith MR, Wilson ML, Hamanaka R, Chase D, Kung $\mathrm{H}$, Longo DL, Ferris DK: Malignant transformation of mammalian cells initiated by constitutive expression of the polo-like kinase. Biochem Biophys Res Commun 1997, 234: 397-405.

26. Eckerdt F, Yuan J, Strebhardt K: Polo-like kinases and oncogenesis. Oncogene 2005, 24: 267-276.

27. Luo J, Emanuele MJ, Li D, Creighton CJ, Schlabach MR, Westbrook TF, Wong KK, Elledge SJ: A genome-wide RNAi screen identifies multiple synthetic lethal interactions with the Ras oncogene. Cell 2009, 137: 835-848.

28. Hu K, Law JH, Fotovati A, Dunn SE: Small interfering RNA library screen identified polo-like kinase-1 (PLK1) as a potential therapeutic target for breast cancer that uniquely eliminates tumor-initiating cells. Breast Cancer Res 2012, 14: R22.

29. Francescangeli F, Patrizii M, Signore M, Federici G, Di FS, Pagliuca A, Baiocchi M, Biffoni M, Ricci VL, Todaro M, De MR, Zeuner A: Proliferation state and polo-like kinase1 dependence of tumorigenic colon cancer cells. Stem Cells 2012, 30: 1819-1830.
30. Harris PS, Venkataraman S, Alimova I, Birks DK, Donson AM, Knipstein J, Dubuc A, Taylor MD, Handler MH, Foreman NK, Vibhakar R: Polo-like kinase 1 (PLK1) inhibition suppresses cell growth and enhances radiation sensitivity in medulloblastoma cells. BMC Cancer 2012, 12: 80 .

31. Lee C, Fotovati A, Triscott J, Chen J, Venugopal C, Singhal A, Dunham C, Kerr JM, Verreault M, Yip S, Wakimoto H, Jones C, Jayanthan A, Narendran A, Singh SK, Dunn SE: Polo-like kinase 1 inhibition kills glioblastoma multiforme brain tumor cells in part through loss of SOX2 and delays tumor progression in mice. Stem Cells 2012, 30: 10641075.

32. Grinshtein N, Datti A, Fujitani M, Uehling D, Prakesch M, Isaac M, Irwin MS, Wrana JL, Al-Awar R, Kaplan DR: Small molecule kinase inhibitor screen identifies polo-like kinase 1 as a target for neuroblastoma tumor-initiating cells. Cancer Res 2011, 71: 1385-1395.

33. Lens SM, Voest EE, Medema RH: Shared and separate functions of polo-like kinases and aurora kinases in cancer. Nat Rev Cancer 2010, 10: 825-841.

34. Taylor S, Peters JM: Polo and Aurora kinases: lessons derived from chemical biology. Curr Opin Cell Biol 2008, 20: 77-84.

35. Keppner S, Proschak E, Kaufmann M, Strebhardt K, Schneider G, Spankuch B: Biological impact of freezing Plk1 in its inactive conformation in cancer cells. Cell Cycle 2010, 9: 761-773.

36. Vose JM, Friedberg JW, Waller EK, Cheson BD, Juvvigunta V, Fritsch H, Petit C, Munzert G, Younes A: The Plk1 inhibitor BI 2536 in patients with refractory or relapsed non-Hodgkin's lymphoma: A Phase I, open-label, single dose-escalation study. Leuk Lymphoma 2012.

37. Jimeno A, Li J, Messersmith WA, Laheru D, Rudek MA, Maniar M, Hidalgo M, Baker SD, Donehower RC: Phase I study of ON 01910.Na, a novel modulator of the Polo-like kinase 1 pathway, in adult patients with solid tumors. J Clin Oncol 2008, 26: 5504-5510.

38. Mross K, Dittrich C, Aulitzky WE, Strumberg D, Schutte J, Schmid RM, Hollerbach S, Merger M, Munzert G, Fleischer F, Scheulen ME: A randomised phase II trial of the Pololike kinase inhibitor BI 2536 in chemo-naive patients with unresectable exocrine adenocarcinoma of the pancreas - a study within the Central European Society Anticancer Drug Research (CESAR) collaborative network. Br J Cancer 2012, 107: 280-286.

39. Mross K, Frost A, Steinbild S, Hedbom S, Rentschler J, Kaiser R, Rouyrre N, Trommeshauser D, Hoesl CE, Munzert G: Phase I dose escalation and pharmacokinetic study of BI 2536, a novel Polo-like kinase 1 inhibitor, in patients with advanced solid tumors. J Clin Oncol 2008, 26: 5511-5517.

40. Schoffski P, Awada A, Dumez H, Gil T, Bartholomeus S, Wolter P, Taton M, Fritsch H, Glomb P, Munzert G: A phase I, dose-escalation study of the novel Polo-like kinase 
inhibitor volasertib (BI 6727) in patients with advanced solid tumours. Eur J Cancer 2012, 48: 179-186.

41. Olmos D, Barker D, Sharma R, Brunetto AT, Yap TA, Taegtmeyer AB, Barriuso J, Medani H, Degenhardt YY, Allred AJ, Smith DA, Murray SC, Lampkin TA, Dar MM, Wilson R, de Bono JS et al.: Phase I study of GSK461364, a specific and competitive Polo-like kinase 1 inhibitor, in patients with advanced solid malignancies. Clin Cancer Res 2011, 17: 3420-3430.

42. Garland LL, Taylor C, Pilkington DL, Cohen JL, Von Hoff DD: A phase I pharmacokinetic study of HMN-214, a novel oral stilbene derivative with polo-like kinase-1-interacting properties, in patients with advanced solid tumors. Clin Cancer Res 2006, 12: 5182-5189.

43. Reindl W, Yuan J, Kramer A, Strebhardt K, Berg T: Inhibition of polo-like kinase 1 by blocking polo-box domain-dependent protein-protein interactions. Chem Biol 2008, 15: 459-466.

44. Yuan J, Sanhaji M, Kramer A, Reindl W, Hofmann M, Kreis NN, Zimmer B, Berg T, Strebhardt K: Polo-box domain inhibitor poloxin activates the spindle assembly checkpoint and inhibits tumor growth in vivo. Am J Pathol 2011, 179: 2091-2099.

45. Lane DP, Crawford LV: T antigen is bound to a host protein in SV40-transformed cells. Nature 1979, 278: 261-263.

46. Linzer DI, Levine AJ: Characterization of a $54 \mathrm{~K}$ dalton cellular SV40 tumor antigen present in SV40-transformed cells and uninfected embryonal carcinoma cells. Cell 1979, 17: 43-52.

47. Levine AJ: The evolution of the p53 family of genes. Cell Cycle 2012, 11: 214-215.

48. Baker SJ, Fearon ER, Nigro JM, Hamilton SR, Preisinger AC, Jessup JM, vanTuinen P, Ledbetter DH, Barker DF, Nakamura Y, White R, Vogelstein B: Chromosome 17 deletions and p53 gene mutations in colorectal carcinomas. Science 1989, 244: 217-221.

49. Nigro JM, Baker SJ, Preisinger AC, Jessup JM, Hostetter R, Cleary K, Bigner SH, Davidson N, Baylin S, Devilee P, $\therefore$ Mutations in the p53 gene occur in diverse human tumour types. Nature 1989, 342: 705-708.

50. Lane DP: Cancer. p53, guardian of the genome. Nature 1992, 358: 15-16.

51. Maddocks OD, Berkers CR, Mason SM, Zheng L, Blyth K, Gottlieb E, Vousden KH: Serine starvation induces stress and p53-dependent metabolic remodelling in cancer cells. Nature 2013, 493: 542-546.

52. Vousden KH, Prives C: Blinded by the Light: The Growing Complexity of p53. Cell 2009, 137: 413-431.

53. Hong H, Takahashi K, Ichisaka T, Aoi T, Kanagawa O, Nakagawa M, Okita K, Yamanaka S: Suppression of induced pluripotent stem cell generation by the p53-p21 pathway. Nature 2009, 460: 1132-1135.

54. Kawamura T, Suzuki J, Wang YV, Menendez S, Morera LB, Raya A, Wahl GM, Belmonte JC: Linking the p53 tumour suppressor pathway to somatic cell reprogramming. Nature 2009, 460: 1140-1144.

55. Li H, Collado M, Villasante A, Strati K, Ortega S, Canamero M, Blasco MA, Serrano M: The Ink4/Arf locus is a barrier for iPS cell reprogramming. Nature 2009, 460: 1136-1139.

56. Marion RM, Strati K, Li H, Murga M, Blanco R, Ortega S, Fernandez-Capetillo O, Serrano M, Blasco MA: A p53mediated DNA damage response limits reprogramming to ensure iPS cell genomic integrity. Nature 2009, 460: 11491153.

57. Utikal J, Polo JM, Stadtfeld M, Maherali N, Kulalert W, Walsh RM, Khalil A, Rheinwald JG, Hochedlinger K: Immortalization eliminates a roadblock during cellular reprogramming into iPS cells. Nature 2009, 460: 11451148.

58. Frezza C, Martins CP: From tumor prevention to therapy: empowering p53 to fight back. Drug Resist Updat 2012, 15: 258-267.

59. Jiang P, Du W, Wang X, Mancuso A, Gao X, Wu M, Yang $\mathrm{X}$ : $\mathrm{p} 53$ regulates biosynthesis through direct inactivation of glucose-6-phosphate dehydrogenase. Nat Cell Biol 2011, 13: $310-316$.

60. Joerger AC, Fersht AR: Structural biology of the tumor suppressor p53. Annu Rev Biochem 2008, 77: 557-582.

61. Kruse JP, Gu W: Modes of p53 regulation. Cell 2009, 137 : 609-622.

62. Horn HF, Vousden KH: Coping with stress: multiple ways to activate p53. Oncogene 2007, 26: 1306-1316.

63. Junttila MR, Evan GI: p53--a Jack of all trades but master of none. Nat Rev Cancer 2009, 9: 821-829.

64. Bode AM, Dong Z: Post-translational modification of p53 in tumorigenesis. Nat Rev Cancer 2004, 4: 793-805.

65. Vogelstein B, Lane D, Levine AJ: Surfing the p53 network. Nature 2000, 408: 307-310.

66. Brown CJ, Lain S, Verma CS, Fersht AR, Lane DP: Awakening guardian angels: drugging the p53 pathway. Nat Rev Cancer 2009, 9: 862-873.

67. Cheok CF, Verma CS, Baselga J, Lane DP: Translating p53 into the clinic. Nat Rev Clin Oncol 2011, 8: 25-37.

68. Brauninger A, Strebhardt K, Rubsamen-Waigmann H: Identification and functional characterization of the human and murine polo-like kinase (Plk) promoter. Oncogene 1995, 11: 1793-1800.

69. Uchiumi T, Longo DL, Ferris DK: Cell cycle regulation of the human polo-like kinase (PLK) promoter. J Biol Chem 1997, 272: 9166-9174.

70. Zhu H, Chang BD, Uchiumi T, Roninson IB: Identification of promoter elements responsible for transcriptional inhibition of polo-like kinase 1 and topoisomerase IIalpha genes by p21(WAF1/CIP1/SDI1). Cell Cycle 2002, 1: 5966.

71. Pandit B, Halasi M, Gartel AL: p53 negatively regulates 
expression of FoxM1. Cell Cycle 2009, 8: 3425-3427.

72. Barsotti AM, Prives C: Pro-proliferative FoxM1 is a target of p53-mediated repression. Oncogene 2009, 28: 42954305.

73. Wang IC, Chen YJ, Hughes D, Petrovic V, Major ML, Park HJ, Tan Y, Ackerson T, Costa RH: Forkhead box M1 regulates the transcriptional network of genes essential for mitotic progression and genes encoding the SCF (Skp2Cks1) ubiquitin ligase. Mol Cell Biol 2005, 25: 1087510894.

74. Fu Z, Malureanu L, Huang J, Wang W, Li H, van Deursen JM, Tindall DJ, Chen J: Plk1-dependent phosphorylation of FoxM1 regulates a transcriptional programme required for mitotic progression. Nat Cell Biol 2008, 10: 1076-1082.

75. Gunawardena RW, Siddiqui H, Solomon DA, Mayhew CN, Held J, Angus SP, Knudsen ES: Hierarchical requirement of SWI/SNF in retinoblastoma tumor suppressor-mediated repression of Plk1. J Biol Chem 2004, 279: 29278-29285.

76. Jackson MW, Agarwal MK, Yang J, Bruss P, Uchiumi T, Agarwal ML, Stark GR, Taylor WR: p130/p107/p105Rbdependent transcriptional repression during DNA-damageinduced cell-cycle exit at G2. J Cell Sci 2005, 118: 18211832.

77. McKenzie L, King S, Marcar L, Nicol S, Dias SS, Schumm K, Robertson P, Bourdon JC, Perkins N, Fuller-Pace F, Meek DW: p53-dependent repression of polo-like kinase-1 (PLK1). Cell Cycle 2010, 9: 4200-4212.

78. Hermeking H: The miR-34 family in cancer and apoptosis. Cell Death Differ 2010, 17: 193-199.

79. Freeman JA, Espinosa JM: The impact of posttranscriptional regulation in the p53 network. Brief Funct Genomics 2013, 12: 46-57.

80. Ugras S, Brill E, Jacobsen A, Hafner M, Socci ND, Decarolis PL, Khanin R, O'Connor R, Mihailovic A, Taylor BS, Sheridan R, Gimble JM, Viale A, Crago A, Antonescu $\mathrm{CR}$, Sander $\mathrm{C}$ et al.: Small RNA sequencing and functional characterization reveals MicroRNA-143 tumor suppressor activity in liposarcoma. Cancer Res 2011, 71: 5659-5669.

81. Shi W, Alajez NM, Bastianutto C, Hui AB, Mocanu JD, Ito E, Busson P, Lo KW, Ng R, Waldron J, O’Sullivan B, Liu FF: Significance of Plk1 regulation by miR-100 in human nasopharyngeal cancer. Int J Cancer 2010, 126: 2036-2048.

82. Liu J, Lu KH, Liu ZL, Sun M, De W, Wang ZX: MicroRNA-100 is a potential molecular marker of nonsmall cell lung cancer and functions as a tumor suppressor by targeting polo-like kinase 1. BMC Cancer 2012, 12: 519.

83. Peng DX, Luo M, Qiu LW, He YL, Wang XF: Prognostic implications of microRNA-100 and its functional roles in human epithelial ovarian cancer. Oncol Rep 2012, 27: 1238-1244.

84. Ito T, Sato F, Kan T, Cheng Y, David S, Agarwal R, Paun BC, Jin Z, Olaru AV, Hamilton JP, Selaru FM, Yang J, Matsumura N, Shimizu K, Abraham JM, Shimada Y et al.: Polo-like kinase 1 regulates cell proliferation and is targeted by miR-593* in esophageal cancer. Int J Cancer 2011, 129: 2134-2146.

85. Biagioni F, Bossel Ben-Moshe N, Fontemaggi G, Canu V, Mori F, Antoniani B, Di BA, Santoro R, Germoni S, De AF, Cambria A, Avraham R, Grasso G, Strano S, Muti P, Mottolese $\mathrm{M}$ et al.: miR-10b*, a master inhibitor of the cell cycle, is down-regulated in human breast tumours. EMBO Mol Med 2012, 4: 1214-1229.

86. King SI, Purdie CA, Bray SE, Quinlan PR, Jordan LB, Thompson AM, Meek DW: Immunohistochemical detection of Polo-like kinase-1 (PLK1) in primary breast cancer is associated with TP53 mutation and poor clinical outcom. Breast Cancer Res 2012, 14: R40.

87. Napoli M, Girardini JE, Piazza S, Del SG: Wiring the oncogenic circuitry: Pin1 unleashes mutant p53. Oncotarget 2011, 2: 654-656.

88. Martynova E, Pozzi S, Basile V, Dolfini D, Zambelli F, Imbriano C, Pavesi G, Mantovani R: Gain-of-function p53 mutants have widespread genomic locations partially overlapping with p63. Oncotarget 2012, 3: 132-143.

89. Neilsen PM, Noll JE, Suetani RJ, Schulz RB, Al-Ejeh F, Evdokiou A, Lane DP, Callen DF: Mutant p53 uses p63 as a molecular chaperone to alter gene expression and induce a pro-invasive secretome. Oncotarget 2011, 2: 1203-1217.

90. Ando K, Ozaki T, Yamamoto H, Furuya K, Hosoda M, Hayashi S, Fukuzawa M, Nakagawara A: Polo-like kinase 1 (Plk1) inhibits p53 function by physical interaction and phosphorylation. J Biol Chem 2004, 279: 25549-25561.

91. Chen J, Dai G, Wang YQ, Wang S, Pan FY, Xue B, Zhao DH, Li CJ: Polo-like kinase 1 regulates mitotic arrest after UV irradiation through dephosphorylation of p53 and inducing p53 degradation. FEBS Lett 2006, 580: 36243630.

92. Yang X, Li H, Zhou Z, Wang WH, Deng A, Andrisani O, Liu X: Plk1-mediated phosphorylation of Topors regulates p53 stability. J Biol Chem 2009, 284: 18588-18592.

93. Dias SS, Hogan C, Ochocka AM, Meek DW: Polo-like kinase-1 phosphorylates MDM2 at Ser260 and stimulates MDM2-mediated p53 turnover. FEBS Lett 2009, 583: 3543-3548.

94. Liu XS, Li H, Song B, Liu X: Polo-like kinase 1 phosphorylation of G2 and S-phase-expressed 1 protein is essential for p53 inactivation during G2 checkpoint recovery. EMBO Rep 2010, 11: 626-632.

95. Liu X, Erikson RL: Polo-like kinase (Plk)1 depletion induces apoptosis in cancer cells. Proc Natl Acad Sci U S A 2003, 100: 5789-5794.

96. Ory B, Ellisen LW: A microRNA-dependent circuit controlling p63/p73 homeostasis: p53 family cross-talk meets therapeutic opportunity. Oncotarget 2011, 2: 259264.

97. Allocati N, Di IC, De L, V: p63/p73 in the control of cell cycle and cell death. Exp Cell Res 2012, 318: 1285-1290.

98. Conforti F, Sayan AE, Sreekumar R, Sayan BS: Regulation 
of p73 activity by post-translational modifications. Cell Death Dis 2012, 3: e285.

99. Koida N, Ozaki T, Yamamoto H, Ono S, Koda T, Ando K, Okoshi R, Kamijo T, Omura K, Nakagawara A: Inhibitory role of Plk1 in the regulation of p73-dependent apoptosis through physical interaction and phosphorylation. J Biol Chem 2008, 283: 8555-8563.

100. Soond SM, Barry SP, Melino G, Knight RA, Latchman DS, Stephanou A: p73-mediated transcriptional activity is negatively regulated by polo-like kinase 1 . Cell Cycle 2008, 7: 1214-1223.

101. Tyagi S, Bhui K, Singh R, Singh M, Raisuddin S, Shukla Y: Polo-like kinase1 (Plk1) knockdown enhances cisplatin chemosensitivity via up-regulation of p73alpha in p53 mutant human epidermoid squamous carcinoma cells. Biochem Pharmacol 2010, 80: 1326-1334.

102. Kreis NN, Sommer K, Sanhaji M, Kramer A, Matthess Y, Kaufmann M, Strebhardt K, Yuan J: Long-term downregulation of Polo-like kinase 1 increases the cyclindependent kinase inhibitor p21(WAF1/CIP1). Cell Cycle 2009, 8: 460-472.

103. Scheffner M, Werness BA, Huibregtse JM, Levine AJ, Howley PM: The E6 oncoprotein encoded by human papillomavirus types 16 and 18 promotes the degradation of p53. Cell 1990, 63: 1129-1136.

104. Komatsu S, Takenobu H, Ozaki T, Ando K, Koida N, Suenaga Y, Ichikawa T, Hishiki T, Chiba T, Iwama A, Yoshida H, Ohnuma N, Nakagawara A, Kamijo T: Plk1 regulates liver tumor cell death by phosphorylation of TAp63. Oncogene 2009, 28: 3631-3641.

105. Lenart P, Petronczki M, Steegmaier M, Di FB, Lipp JJ, Hoffmann M, Rettig WJ, Kraut N, Peters JM: The smallmolecule inhibitor BI 2536 reveals novel insights into mitotic roles of polo-like kinase 1. Curr Biol 2007, 17: 304315.

106. Rudolph D, Steegmaier M, Hoffmann M, Grauert M, Baum A, Quant J, Haslinger C, Garin-Chesa P, Adolf GR: BI 6727, a Polo-like kinase inhibitor with improved pharmacokinetic profile and broad antitumor activity. Clin Cancer Res 2009, 15: 3094-3102.

107. Steegmaier M, Hoffmann M, Baum A, Lenart P, Petronczki M, Krssak M, Gurtler U, Garin-Chesa P, Lieb S, Quant J, Grauert M, Adolf GR, Kraut N, Peters JM, Rettig WJ: BI 2536, a potent and selective inhibitor of polo-like kinase 1, inhibits tumor growth in vivo. Curr Biol 2007, 17: 316-322.

108. Yuan J, Kramer A, Eckerdt F, Kaufmann M, Strebhardt K: Efficient internalization of the polo-box of polo-like kinase 1 fused to an Antennapedia peptide results in inhibition of cancer cell proliferation. Cancer Res 2002, 62: 4186-4190.

109. Watanabe N, Sekine T, Takagi M, Iwasaki J, Imamoto N, Kawasaki H, Osada H: Deficiency in chromosome congression by the inhibition of Plk1 polo box domaindependent recognition. J Biol Chem 2009, 284: 2344-2353.

110. Schoffski P: Polo-like kinase (PLK) inhibitors in preclinical and early clinical development in oncology. Oncologist 2009, 14: 559-570.

111. Sebastian M, Reck M, Waller CF, Kortsik C, Frickhofen N, Schuler M, Fritsch H, Gaschler-Markefski B, Hanft G, Munzert G, von PJ: The efficacy and safety of BI 2536, a novel Plk-1 inhibitor, in patients with stage IIIB/IV nonsmall cell lung cancer who had relapsed after, or failed, chemotherapy: results from an open-label, randomized phase II clinical trial. J Thorac Oncol 2010, 5: 1060-1067.

112. Liu X, Lei M, Erikson RL: Normal cells, but not cancer cells, survive severe Plk1 depletion. Mol Cell Biol 2006, 26: 2093-2108.

113. Lansing TJ, McConnell RT, Duckett DR, Spehar GM, Knick VB, Hassler DF, Noro N, Furuta M, Emmitte KA, Gilmer TM, Mook RA, Jr., Cheung M: In vitro biological activity of a novel small-molecule inhibitor of polo-like kinase 1. Mol Cancer Ther 2007, 6: 450-459.

114. Spankuch-Schmitt B, Bereiter-Hahn J, Kaufmann M, Strebhardt K: Effect of RNA silencing of polo-like kinase-1 (PLK1) on apoptosis and spindle formation in human cancer cells. J Natl Cancer Inst 2002, 94: 1863-1877.

115. Raab M, Kappel S, Kramer A, Sanhaji M, Matthess Y, Kurunci-Csacsko E, Calzada-Wack J, Rathkolb B, Rozman J, Adler T, Busch DH, Esposito I, Fuchs H, Gailus-Durner $\mathrm{V}$, Klingenspor M, Wolf $\mathrm{E}$ et al.: Toxicity modelling of Plk1-targeted therapies in genetically engineered mice and cultured primary mammalian cells. Nat Commun 2011, 2: 395.

116. Lu B, Mahmud H, Maass AH, Yu B, van Gilst WH, de Boer RA, Sillje HH: The Plk1 inhibitor BI 2536 temporarily arrests primary cardiac fibroblasts in mitosis and generates aneuploidy in vitro. PLoS One 2010, 5: e12963.

117. Maire V, Nemati F, Richardson M, Vincent-Salomon A, Tesson B, Rigaill G, Gravier E, Marty-Prouvost B, De KL, Lang G, Gentien D, Dumont A, Barillot E, Marangoni E, Decaudin D, Roman-Roman S et al.: Polo-like kinase 1: a potential therapeutic option in combination with conventional chemotherapy for the management of patients with triple-negative breast cancer. Cancer Res 2013, 73: 813-823.

118. Frost A, Mross K, Steinbild S, Hedbom S, Unger C, Kaiser R, Trommeshauser D, Munzert G: Phase i study of the Plk1 inhibitor BI 2536 administered intravenously on three consecutive days in advanced solid tumours. Curr Oncol 2012, 19: e28-e35.

119. Degenhardt Y, Greshock J, Laquerre S, Gilmartin AG, Jing J, Richter M, Zhang X, Bleam M, Halsey W, Hughes A, Moy C, Liu-Sullivan N, Powers S, Bachman K, Jackson J, Weber B et al.: Sensitivity of cancer cells to Plk1 inhibitor GSK461364A is associated with loss of p53 function and chromosome instability. Mol Cancer Ther 2010, 9: 20792089.

120. Guan R, Tapang P, Leverson JD, Albert D, Giranda VL, Luo Y: Small interfering RNA-mediated Polo-like kinase 1 depletion preferentially reduces the survival of p53- 
defective, oncogenic transformed cells and inhibits tumor growth in animals. Cancer Res 2005, 65: 2698-2704.

121. Morris VB, Brammall J, Noble J, Reddel R: p53 localizes to the centrosomes and spindles of mitotic cells in the embryonic chick epiblast, human cell lines, and a human primary culture: An immunofluorescence study. Exp Cell Res 2000, 256: 122-130.

122. Ciciarello M, Mangiacasale R, Casenghi M, Zaira LM, D'Angelo M, Soddu S, Lavia P, Cundari E: p53 displacement from centrosomes and p53-mediated G1 arrest following transient inhibition of the mitotic spindle. J Biol Chem 2001, 276: 19205-19213.

123. Gully CP, Velazquez-Torres G, Shin JH, Fuentes-Mattei E, Wang E, Carlock C, Chen J, Rothenberg D, Adams HP, Choi HH, Guma S, Phan L, Chou PC, Su CH, Zhang F, Chen JS et al.: Aurora B kinase phosphorylates and instigates degradation of p53. Proc Natl Acad Sci U S A 2012, 109: E1513-E1522.

124. Andreassen PR, Lacroix FB, Lohez OD, Margolis RL: Neither p21WAF1 nor 14-3-3sigma prevents G2 progression to mitotic catastrophe in human colon carcinoma cells after DNA damage, but p21WAF1 induces stable G1 arrest in resulting tetraploid cells. Cancer Res 2001, 61: 7660-7668.

125. Vogel C, Kienitz A, Hofmann I, Muller R, Bastians H: Crosstalk of the mitotic spindle assembly checkpoint with p53 to prevent polyploidy. Oncogene 2004, 23: 6845-6853.

126. Sanhaji M, Kreis NN, Zimmer B, Berg T, Louwen F, Yuan $\mathrm{J}$ : p53 is not directly relevant to the response of Polo-like kinase 1 inhibitors. Cell Cycle 2012, 11.

127. Wu CC, Yang TY, Yu CT, Phan L, Ivan C, Sood AK, Hsu SL, Lee MH: p53 negatively regulates Aurora A via both transcriptional and posttranslational regulation. Cell Cycle 2012, 11: 3433-3442.

128. Chiang CM: p53-Aurora A mitotic feedback loop regulates cell cycle progression and genomic stability. Cell Cycle 2012, 11: 3719 .

129. Oricchio E, Saladino C, Iacovelli S, Soddu S, Cundari E: ATM is activated by default in mitosis, localizes at centrosomes and monitors mitotic spindle integrity. Cell Cycle 2006, 5: 88-92.

130. Tritarelli A, Oricchio E, Ciciarello M, Mangiacasale R, Palena A, Lavia P, Soddu S, Cundari E: p53 localization at centrosomes during mitosis and postmitotic checkpoint are ATM-dependent and require serine 15 phosphorylation. Mol Biol Cell 2004, 15: 3751-3757.

131. Doxsey S, Zimmerman W, Mikule K: Centrosome control of the cell cycle. Trends Cell Biol 2005, 15: 303-311.

132. Fukasawa K: Oncogenes and tumour suppressors take on centrosomes. Nat Rev Cancer 2007, 7: 911-924.

133. Cross SM, Sanchez CA, Morgan CA, Schimke MK, Ramel S, Idzerda RL, Raskind WH, Reid BJ: A p53-dependent mouse spindle checkpoint. Science 1995, 267: 1353-1356.

134. Kuffer C, Kuznetsova AY, Storchova Z: Abnormal mitosis triggers p53-dependent cell cycle arrest in human tetraploid cells. Chromosoma 2013.

135. Allison SJ, Milner J: Remodelling chromatin on a global scale: a novel protective function of p53. Carcinogenesis 2004, 25: 1551-1557.

136. Allison SJ, Milner J: Loss of p53 has site-specific effects on histone $\mathrm{H} 3$ modification, including serine 10 phosphorylation important for maintenance of ploidy. Cancer Res 2003, 63: 6674-6679.

137. Ha GH, Baek KH, Kim HS, Jeong SJ, Kim CM, McKeon $\mathrm{F}$, Lee $\mathrm{CW}$ : p53 activation in response to mitotic spindle damage requires signaling via BubR1-mediated phosphorylation. Cancer Res 2007, 67: 7155-7164.

138. Huang YF, Chang MD, Shieh SY: TTK/hMps1 mediates the p53-dependent postmitotic checkpoint by phosphorylating p53 at Thr18. Mol Cell Biol 2009, 29: 2935-2944.

139. Ha GH, Breuer EK: Mitotic Kinases and p53 Signaling. Biochem Res Int 2012, 2012: 195903.

140. Sur S, Pagliarini R, Bunz F, Rago C, Diaz LA, Jr., Kinzler KW, Vogelstein B, Papadopoulos N: A panel of isogenic human cancer cells suggests a therapeutic approach for cancers with inactivated p53. Proc Natl Acad Sci U S A 2009, 106: 3964-3969.

141. Sanhaji M, Louwen F, Zimmer B, Kreis NN, Roth S, Yuan J: Polo-like kinase 1 inhibitors, mitotic stress and the tumor suppressor p53. Cell Cycle 2013, 12.

142. Khan SH, Wahl GM: p53 and pRb prevent rereplication in response to microtubule inhibitors by mediating a reversible G1 arrest. Cancer Res 1998, 58: 396-401.

143. Stewart ZA, Mays D, Pietenpol JA: Defective G1-S cell cycle checkpoint function sensitizes cells to microtubule inhibitor-induced apoptosis. Cancer Res 1999, 59: 38313837.

144. Manchado E, Guillamot M, Malumbres M: Killing cells by targeting mitosis. Cell Death Differ 2012, 19: 369-377.

145. Jackson JR, Patrick DR, Dar MM, Huang PS: Targeted antimitotic therapies: can we improve on tubulin agents? Nat Rev Cancer 2007, 7: 107-117.

146. Sanhaji M, Friel CT, Wordeman L, Louwen F, Yuan J: Mitotic centromere-associated kinesin (MCAK): a potential cancer drug target. Oncotarget 2011, 2: 935-947.

147. Liu-Sullivan N, Zhang J, Bakleh A, Marchica J, Li J, Siolas D, Laquerre S, Degenhardt YY, Wooster R, Chang K, Hannon GF, Powers S: Pooled shRNA screen for sensitizers to inhibition of the mitotic regulator polo-like kinase (PLK1). Oncotarget 2011, 2: 1254-1264.

148. Spankuch B, Heim S, Kurunci-Csacsko E, Lindenau C, Yuan J, Kaufmann M, Strebhardt K: Down-regulation of Polo-like kinase 1 elevates drug sensitivity of breast cancer cells in vitro and in vivo. Cancer Res 2006, 66: 5836-5846.

149. Spankuch B, Kurunci-Csacsko E, Kaufmann M, Strebhardt $\mathrm{K}$ : Rational combinations of siRNAs targeting Plk1 with breast cancer drugs. Oncogene 2007, 26: 5793-5807.

150. Chen JG, Yang CP, Cammer M, Horwitz SB: Gene 
expression and mitotic exit induced by microtubulestabilizing drugs. Cancer Res 2003, 63: 7891-7899.

151. Swanton C, Marani M, Pardo O, Warne PH, Kelly G, Sahai E, Elustondo F, Chang J, Temple J, Ahmed AA, Brenton JD, Downward J, Nicke B: Regulators of mitotic arrest and ceramide metabolism are determinants of sensitivity to paclitaxel and other chemotherapeutic drugs. Cancer Cell 2007, 11: 498-512.

152. Blagosklonny MV: Prolonged mitosis versus tetraploid checkpoint: how p53 measures the duration of mitosis. Cell Cycle 2006, 5: 971-975.

153. Ellis PM, Chu QS, Leighl N, Laurie SA, Fritsch H, Gaschler-Markefski B, Gyorffy S, Munzert G: A Phase I Open-Label Dose-Escalation Study of Intravenous BI 2536 Together With Pemetrexed in Previously Treated Patients With Non-Small-Cell Lung Cancer. Clin Lung Cancer 2012.

154. Blagosklonny MV: Wt p53 impairs response to chemotherapy: make lemonade to spare normal cells. Oncotarget 2012, 3: 601-607.

155. van Leeuwen IM: Cyclotherapy: opening a therapeutic window in cancer treatment. Oncotarget 2012, 3: 596-600. 